\title{
Citizenship and National Identity in Early Meiji Japan, 1868-1889: A Comparative Assessment*
}

\section{EIKO IKEGAMI}

After the collapse of the long-standing Tokugawa regime (1603-1867), Japan under the Meiji emperor (1867-1912) rapidly implemented the process of modern nation-building by effectively utilizing the venerable institution of the emperor (Tennō) as its new national symbol. Following the imperial restoration, the Meiji government abolished the socioeconomic and political privileges of the samurai class, namely its exclusive right to bear arms, hold office and receive hereditary stipends. By 1900, Japan had already equipped itself with a modern Constitution that defined citizens' rights and obligations, a parliamentary system, an updated judicial system, universal education, a restructured national and local bureaucracy, national standing army, private ownership of land, and a nation-wide taxation system. None of these institutions had existed prior to 1868. All of the developmental innovations listed above were instituted within little more than a quarter century after the collapse of their predecessor's political structures. Before the Meiji restoration, Japanese society had been governed exclusively by its hereditary samurai elites for two and a half centuries. It was only during the early Meiji period - a little more than two decades or so - that the concept of kokumin (usually translated as "citizen", more literally "country-person") entered the popular vocabulary for the first time in Japanese history. The complex social and political dynamics of this initial period of development for Japanese citizenship rights is the primary object of my inquiry.

Japan's first modern Constitution (1889) defined the emperor as the source of supreme sovereign power, at the same time that it codified the civic rights of "imperial subjects", including freedom of speech and religion, property rights and political participation through a parliamentary system. These provisions were by no means ideal from a modern liberal democratic perspective, in so far as they were coupled with assertion of the emperor's divine power and authority. Under the terms of the 1889 Constitution, sovereignty was vested in the emperor alone, on the basis of his "unbroken mythic" bloodline, but actual exercise of power was divided between a bicameral Diet and a Cabinet. Given the

\footnotetext{
* I would like to thank Reid Andrews, Herrick Chapman, Betsy Fray, Michael Mosher and Charles Tilly for helpful comments on an earlier draft of this paper. A version of this paper was presented at the 1994 Annual Meeting of the American Sociological Association in Los Angeles, and at a conference on "Social Construction of Democracy" at the University of Pittsburgh in 1992.
} 
fact that Japan did not have either a tradition of citizenship or experience of parliamentary rule, this formal codification and institutionalization of political citizenship was a watershed in its history. During the first two decades of the twentieth century, Japan further extended the suffrage, and parliamentary partisan politics acquired a solid institutional form. Even though these temporary achievements of democracy were dismantled in the 1930s during the rise of anti-democratic militarism, the gradual expansion of liberal-political institutions during this earlier transitional period stood in partial contradiction to the authoritarian image of the pre-war Japanese state.

In this paper, I shall examine the institution of citizenship in Meiji Japan as the outcome of processes in which a variety of social forces interactively shaped public discourse in a particular historical contingency. I define "citizenship" as a set of negotiated relationships between the state and its members, entailing certain provisions for individuals' rights and obligations that define their relationships. The construction of citizenship as a political relationship rests upon shared, but also often simultaneously contested, understandings of the social identities of the state's members, as well as that of the state itself (i.e. nationhood). I stress the importance of process in this set of interactions, because it was this search for the social construction of individual and collective identity that clearly distinguished the political experience of Meiji Japan from that of its feudal predecessor. Before the collapse of the Tokugawa shogunate in the middle of the nineteenth century, political relations between the government and individual subjects were never considered negotiable entities, at least officially. Only with the passing of the shogunate and the subsequent establishment of the Meiji restoration, did open public discussion of the nature of the Japanese state and its actual and potential relationships to the general population emerge as a significant factor in the political process.

The idea and institution of "citizenship" is of Western provenance. The modern version of citizenship, which assumes an egalitarian principle of membership in the state, is also a Western product associated with the rise of the nation-state, democracy and a mature civil society. Thus, the development of citizenship in non-Western societies is conventionally measured according to the extent of their importation of Western ideas and institutions. If we evaluate non-Western definitions of citizenship only in terms of concepts and law codes, the Meiji Constitution's definition of the Japanese people as "subjects" (shinmin) of the divine emperor is hardly an impressive instance of importation. The case of Meiji Japan is a significant chapter in the history of citizenship, however, not because of the resultant legal provisions (i.e. the extent of citizens' legal claims on the state), but rather because of its accrued political experience; that is, the process of bargaining and negotiation that defined the relationship between the government and its population. The Meiji period was the 
first time in Japanese history that new identities of the Japanese people and the Japanese state were seriously influenced by and reformulated through emerging vehicles of public debate.

I consider that the general rubric of the notion of citizenship allows for a multiplicity of possible relations between governments and their populations. The Japanese variant was a product of borrowing from Western models, improvisation and deliberate invention within the strict constraints of a historical context. The articulation of this historical context allows for an exploration of the seemingly paradoxical nature of Meiji citizenship, which I propose to do in this paper. The first question concerns the apparent contradiction between the elitist nature of the Meiji oligarchy and its acceptance of a modicum of popular political participation. Given its authoritarian image, why did the Meiji oligarchy make sizable concessions to popular oppositional demands, and allow the institution of at least some degree of civic and political rights? At the same time, why was this seemingly "modernist" attempt at legal reform tied to the formal institutionalization of the emperor system, which eventually grew to monstrous proportions and ushered Japan into the military authoritarianism of the 1930s? In other words, how could Japan's initial attempt to construct formal relationships between government and citizens, based as it was on a shared understanding of collective identity, issue in the creation of an authoritarian imperial ideology?

\section{THE CONVENTIONAL IMAGE OF MEIJI JAPAN IN THE SOCIAL SCIENCES}

Social scientists have tended to view Meiji Japan as an example of the authoritarian as opposed to the democratic path of English or French political developments - as articulated by the famous thesis of Barrington Moore - of "dictatorship" as compared to "democracy". 1 The Meiji imperial restoration was a typical "revolution from above" that forcefully imposed economic modernization while intentionally retarding the democratization of the political process. ${ }^{2}$ This understanding is often elabo-

${ }^{1}$ Barrington Moore, Jr., Social Origins of Dictatorship and Democracy: Lord and Peasant in the Making of the Modern World (Boston, 1966).

2 Ibid., pp. 433-452; Ellen Kay Trimberger, Revolution from Above (New Brunswick, NJ, 1978). This perspective is in at least partial agreement with the writings of post-war Japanese leftist and liberal scholars, who have focused on this question: what prevented Japan from becoming a modern society in a liberal-democratic sense? In their views, Meiji Japan essentially took the first step on the fatal path toward militaristic authoritarianism and the catastrophe of 1945 . To be sure, some scholars have articulated a "positive" evaluation of Meiji Japan. When the recovery and rapid expansion of the Japanese post-war economy became conspicuous, and a new set of liberal-democratic institutions, including civic and political citizenship appeared to take root, Western Japanese specialists began to describe Meiji Japan as the positive source of both economic and political developments. Pre-war institutional developments do provide some clues to explain the 
rated in conjunction with the late development thesis. Because late developing nations were supposedly eager to catch up with more economically advanced nations, late developers tended to sacrifice democratization and extension of citizens' rights.

Grouping the Japanese pattern of social development with that of Germany is a popular comparative strategy in this regard; it has been employed by such different writers as Barrington Moore, Richard Bendix and Michael Mann. ${ }^{3}$ Japan entered the phase of building a modern nation-state immediately following a prolonged period of feudalism under a dominant military class, a pattern that resembles the German course of social development. A resulting common assumption of these comparative strategies is the image of Meiji Japan as a strong state, with power (à la Bismarck) exercised by a relatively cohesive oligarchic leadership and backed by firm imperial authority.

The present writer questions the overly simplistic account of Meiji Japan as a "revolution from above" that exemplified state control and subordination of the Japanese people. As I will demonstrate below, the reforms of the Meiji period met with widespread resistance on the part of the general population as well as the samurai. This opposition in turn led to bargain-making and alterations of government policy. It is also important to note that government leadership in the early Meiji period was not as cohesive and stable as is often suggested. A detailed examination of early Meiji political development indicates that the leadership's vulnerability rather than its strengths accounts for its bold initiatives toward modern institution-building. Although in the past, the application of the "revolution from above" model to Meiji Japan was a useful means to introduce Japan into comparative discussions, the current state of sociological discussion, specifically its over-reliance on this conceptual tool - runs the risk of obscuring the dimension of negotiation in the process of Meiji nation-building. A more nuanced understanding of Japan's nineteenth-century construction of national identity and citizenship also requires reassessment of the use of the German analogy. This reassessment will be presented in the final section of this paper.

In his classic study of the experience of the British working class, T.H. Marshall outlined an evolutionary argument in which he identified

rapid adoption of economic and political reforms after 1945. Japanese social scientists are still generally reserved about positive evaluations of Meiji Japan, especially in the field of political developments - with good reason.

${ }^{3}$ Moore, Social Origins; Richard Bendix, Nation-Building and Citizenship (2nd ed., Berkeley, 1977); Michael Mann, "Ruling Class Strategies and Citizenship", Sociology, 21 (1987), pp. 339-354. Mann has classified Japanese development under the Meiji regime as an "authoritarian monarchist strategy", together with German, Austrian, and Russian examples. 
three stages of development of modern citizenship rights: civic, political and social. ${ }^{4}$ By the eighteenth century, adult male members of British communities gradually attained the civil legal rights necessary for individual freedom, such as freedom of religion, thought and speech, as well as the right to hold property. Political citizenship emerged in the nineteenth century as the right of participation in the exercise of political power. The third stage, social citizenship, covers the whole range of rights "from a modicum of economic welfare and security to the right to share to the full in the social heritage and to live the life of a civilized being" that developed only in the twentieth century with the emergence of the welfare state and social democracy. Many scholars agree with Marshall that the expansion of citizenship rights, such as property rights and popular political participation, was related to the legal necessities of an emerging capitalist society.

Though Marshall's analytical classification is a useful articulation of the contemporary multi-dimensional concept of citizenship, his evolutionary conception of the development of citizenship rights is not universally applicable. In the case of Meiji Japan, the concept of rights or civil liberties did not exist before the rise of the modern nation-state in the late nineteenth century. Western ideologies of civic liberty were unknown to Tokugawa Japan because of the shogunate's two centuries of isolationist policy. Furthermore, the social preconditions that fostered peculiarly Western notions of citizenship were absent in Japan. In the European experience, the historical traditions of modern citizenship can be traced to the civic culture of the Greek polis as well as to the political autonomy of the medieval mercantile towns. Although Japan produced several exceptions, such as the city of Sakai for a brief period in the sixteenth century, Japanese cities did not for the most part achieve an impressive degree of autonomy and independence during the pre-modern period. No Japanese city could be said to correspond to the city-states or merchant cities of medieval Europe, such as Genoa, Venice, or the prosperous towns of the Netherlands. Most major cities in modern Japan originated as castle towns of the feudal daimyo lords in the sixteenth to seventeenth centuries, and were governed exclusively by a small number of samurai administrators until the late nineteenth century. Thus, commoners residing in these castle cities did not acquire any political privileges or civic liberties. Given this relative weakness of organized power of capital compared to feudal power, the bourgeoisie played a very small role in the political developments of the Meiji Restoration. Therefore, the leaders of Meiji Japan struggled to codify and institute civic and political rights (in the sense of T.H. Marshall's

4 T.H. Marshall, "Citizenship and Social Class", in T.H. Marshall (ed.), Class, Citizenship, and Social Development (New York, 1964). 
usage) while simultaneously striving to create a modern sense of national identity - all within a very short period without the preceding development of a civil society.

The vocabulary of the Japanese language reflects this situation. During the late nineteenth century, Japanese intellectuals single-handedly coined and popularized numerous neologisms in order to domesticate previously unknown Western concepts. Instead of direct translations of the term "citizenship" (shiminken) or "citizen" (shimin), an array of terms such as kokumin (literally "the people of the country", but used as an approximate synonym of the English "citizen"), minken ("people's rights") or kokuseki ("nationality") - have been widely used in intellectual discussions. The term shiminken ("citizenship") is not used in Japanese legal texts, but primarily refers to citizenship as it is understood in Western societies. A strong preference for the root koku ("country") over the root shi (city) in order to express the concept of citizenship reveals the underlying Japanese social process, in which the emergence of citizenship rights coincided with modern nation-building without the prior development of civic society.

The role of the state and the process of state formation, rather than the role of the urban bourgeoisie, appears to be critical for understanding this "take-off" period for citizenship rights in early Meiji Japan. Since the speeding-up of economic development and industrialization took place in the later Meiji period, the conventional thesis emphasizing the temporal connection between citizenship rights and rapid capitalist development does not hold up in this instance. (Parenthetically, it should be noted that the urban middle and working classes played a much more important role in the expansion of popular rights in the early twentieth century, when industrialization took firm root in Japan..$^{6}$ )

An analysis based on a state-centered approach, however, has its own pitfalls if we assume the presence of a strong, capable state as an automatic given for late developers. We must note that the most important task of a newly emerging state after the breakdown of the older system is the sustenance of popular loyalty. This task becomes particularly difficult when the new state's most pressing agenda is the importation of foreign institutions as the foundation of its reconstituted social structure. The alien character of the model itself may often trigger a systemic allergic reaction within the body politic. We often mistakenly assume that the imitation of a foreign system by late developers - in

s Eiko Ikegami and Charles Tilly, "State Formations and Contention in Japan and France", in John M. Merriman, James L. McClain and Ugawa Kaoru (eds), Edo and Paris (Ithaca, NY, 1995), pp. 429-454; Gilbert Rozman, Urban Networks in Ch'ing China and Tokugawa Japan (Princeton, NJ, 1973).

- See for example Andrew Gordon, Labor and Imperial Democracy in Prewar Japan (Berkeley, 1991); Stephen Large, The Rise of Labor in Japan-Yüaikai 1912-19 (Tokyo, 1972). 
comparison with the introduction of a completely novel system - does not require risk-taking. However, it is precisely the reproduction of a foreign model which often involves enormous social risks for individuals within the developing society. Borrowing from foreign cultures and polities has the potential to trigger widespread resentment and discontent, and may lead eventually to open rebellion, violence and fragmentation of the new regime.

The current problem of the Russian state, namely its attempt to import a Western capitalist model of government within a society long dominated by a feudalistic socialist regime, in this sense resembles the problem that the Meiji state had confronted a century earlier. If we can dispense with the myth of "Japanese exceptionalism" - i.e. the notion that the Japanese have a built-in predisposition to social solidarity and, hence, acquiescence to a strong state - we can better perceive and reevaluate the Japanese experience of simultaneously constructing a sense of national identity and citizenship. Japan's formation of a modern nation-state took place upon a contested terrain that required "working out a relationship between conflicting identities".?

We cannot very well imagine the vulnerability of the early Meiji oligarchy if we examine it from the viewpoint of the later Meiji period, when Japan's nationhood, based upon a constitutional monarchy, was firmly institutionalized. The picture of the authoritarian Meiji state crowned by the emperor's formidable authority was, in many ways, the product of a government-sponsored political education campaign on an unprecedented scale, intended to promote a paternalistic image of the emperor and a patriotic civil morality. ${ }^{8}$ In earlier periods of Japanese history, the imperial authority was hardly a given, as it had been little more than a cipher for several centuries. Furthermore, the connection between the oligarchy and the emperor had never been formalized, a situation which posed serious problems of legitimacy for the early Meiji regime. The difficulty of mobilizing popular support for the project of nation-building was another important factor in understanding the development of public discourse in the early Meiji period.

The process of instituting civic and political citizenship rights in Meiji Japan must be understood in terms of the complex interplay between popular movements of opposition, the Meiji oligarchs and institutional arrangements, in a contingent historical situation. The trajectory of public debate for the first two decades of the Meiji regime was conditioned by mutually interrelated institutional environments. These included a need

7 Tetsuo Najita, Japan: The Intellectual Foundations of Modern Japanese Politics (Chicago, 1974), p. 148.

Regarding late Meiji construction and promotion of the imperial ideology, the reader is referred to Carol Gluck, Japan's Modern Myths: Ideology in the Late Meiji Period (Princeton, 1985); Kano Masanao, "Mejji kōki ni okeru kokumin soshikika no katei", in Kano Masanao (ed.), Ronshū nihon rekishi - Rikken seiji (Tokyo, 1975). 
to overcome the legacy of Tokugawa feudalism on the one hand, and the need to oppose Western imperialist pressures on the other. These two preconditions for nation-building significantly influenced the range of choice that the Meiji government could take in the construction of its new state system. In the analysis which follows, I shall examine four facets of this process, namely (1) the distinctive structures of the Tokugawa state which produced important institutional constraints on its successor; (2) the impact of Western imperialism and the timing of Japan's re-entry into world politics; (3) the internal struggles and strategies of the ruling elite; and (4) the interactions between the Meiji leadership and various opposition forces, most notably the Jiyu minken undō or Freedom and People's Rights Movements that focused public discussion on the style of political citizenship.

\section{DOMESTIC AND INTERNATIONAL PRECONDITIONS FOR DEVELOPMENT OF CITIZENSHIP IN THE MEIJI PERIOD}

\section{FROM THE TOKUGAWA STATE TO THE MEIJI STATE}

After more than a hundred years of continuous civil wars among rival warlords, the Tokugawa shoguns achieved the domestic pacification of Japan around 1600 . Following its sweeping military victory, the shogunate reorganized the hierarchical structures of the samurai class while effectively demilitarizing the non-samurai population. The ideology of the Tokugawa state held that commoners were released from the medieval burden of self-defense, because they were protected by the samurai who had the exclusive right to bear arms. ${ }^{9}$ The Tokugawa neo-feudal state which governed the country for the next two and a half centuries (1603-1867) possessed five distinctive organizational features that deserve consideration in this context:

1 A hierarchically integrated yet decentralized state system: the authority of the Tokugawa shogun was firmly established as the public authority (kōgi). However, about 260 regional daimyō still retained semiautonomous power over their local subjects, since they fielded their own armies of samurai vassals. During the two and a half centuries of domestic peace, the daimyö's military forces were "frozen" under the pax Tokugawa. However, the loyalty of the samurai vassals was

9 The logic was articulated in the well-known "Sword Hunt Edict" of Toyotomi Hideyoshi, promulgated in 1588, which ordered the confiscation of all weapons from villagers. The Tokugawa state basically inherited this logic. For a comparative sociological evaluation of Tokugawa state formation, the reader is referred to Eiko Ikegami, The Taming of the Samurai: Honorific Individualism and the Making of Modern Japan (Cambridge, MA, 1995). 
primarily attached to their immediate masters, the daimyō, rather than to the shogun.

2 Indirect methods of social control: the central government of the Tokugawa shogunate did not develop institutions of social control that directly governed individuals. The Tokugawa regime had no central system of taxation, standing armies, police system or national bureaucracy. Instead, the shoguns reorganized various preexisting social organizations (villages, occupational groups, families) which had been previously more or less autonomous, to serve the ends of the state; for example, villages were held collectively responsible for the payment of grain taxes. These mid-range organizations retained considerable disciplinary power over their members. This power was backed by governmental sanctions.

3 "Vassalic bureaucracy" as the organizational foundation of the Tokugawa state: the Tokugawa shogunate as well as the larger local daimyo governments developed a highly sophisticated system of bureaucracy built upon the organizational structure of samurai vassalage. In this closed lineage-oriented hierarchy, a samurai's relative position within the hierarchy of a local or the central government was largely determined by the fixed hereditary ranking of the samurai houses. The samurai's income, prestige and access to power differed according to their house rankings.

4 A rigid system of status distinction: the status system became central to Tokugawa politics. The commoners, or the non-samurai population, were disarmed by decree, and defined as persons protected by and subordinated to the samurai. Moreover, the members of non-samurai status groups were completely excluded from participation in formal political processes. Exclusion on the basis of status worked in both directions: the samurai were not allowed to engage in commercial activities, while farmers or merchants could not assume government or military positions. There was no concept of the equality of people under law in this status-oriented society.

5 Law understood as written commands: Tokugawa rulers established their authority as absolute, and all Tokugawa laws ( $h \bar{o})$ issued solely from the shogun's authority. There was no representative body of any sort to curb his power. Furthermore, Japan lacked an equivalent of the European concepts of divine and natural law, to which European absolutist monarchs were theoretically subject. ${ }^{10}$

At the outset of the nineteenth century, the inadequacy of this system became increasingly apparent, especially in the face of Western intrusiveness. The shogunate's central and local daimyo governments, with their old-fashioned structures and degenerating tax base, lacked the

${ }^{10}$ Regarding studies in English of pre-modern Japanese law, see John Owen Haley, Authority without Power (Oxford, 1991). 
resources for an effective response to social upheavals and Western military threats. Indeed, the mature structure of the Meiji state was the direct antithesis to that of the Tokugawa state, with respect to the five points previously enumerated. Let me summarize the Meiji innovations by way of contrast:

1 The shogunate's decentralized structure was replaced with an emphasis on national political integration and the consequent abolition of the daimyo system. The ancient institution of the emperor was revitalized as the nation's center of loyalty.

2 In contrast to the absence of central institutions of social control under the Tokugawa, the Meiji regime imported Western models of central institutions, by which the government wielded direct control over the lives of individuals. Japan now boasted a national standing army based upon universal conscription, national taxation, a police force, a centralized system of public education and a national system of jurisprudence.

3 The vassalic bureaucracy of the Tokugawa state was replaced, though gradually, by a meritocratic system of bureaucratic recruitment, open to persons from all social status groups. The introduction of universities together with a system of civil service examinations facilitated the development of the meritocratic system.

4 The earlier classification of the population by status groupings was superseded by the concept of "citizen" (kokumin) and "subject" (shinmin). The abolition of status restrictions facilitated all citizens' participation in the political process as well as in economic activities.

5 The construction of modern (= Western) legal and judicial systems, together with the establishment of a constitutional monarchy and parliamentary system.

To be sure, Japan was very different from many non-Western societies lacking prior experience of effective and coherent state systems when they first confronted the threat of Western imperialism. Even so, the historian is left with one question, namely the reasons for the samurai elite's option for complete replacement of the Tokugawa system rather than half-way measures and partial modifications. What made these radical social reforms possible, even though the Meiji restoration was carried out by a sector of the samurai class itself? This question brings us to the timing of Japan's re-entry into world politics, and the nature of the sense of crisis shared by those who carried out the Meiji restoration.

\section{NATIONALISM BEFORE THE NATION-STATE}

From a long-term comparative perspective, the political situation of late medieval Europe and that of late medieval Japan had a number of similarities. The various European societies as well as Japan confronted 
internal turmoil resulting from the crises of late feudalism, in which barons and warlords continuously fought each other for hegemony. Japan's triumphant consolidation of power under the Tokugawa around 1600 appeared to conform to the pattern of the emerging European absolutist states. However, unlike its Western counterparts, which subsequently moved in the direction of the construction of modern nationstates, Japan maintained its idiosyncratic structure of a neo-feudal garrison state dominated by a warrior class for another two and a half centuries. Furthermore, the European states were in the process of developing elaborate organizational arms of social control, such as national standing armies, police, public education, meritocratic bureaucracies, and modern fiscal systems. The gap between the Western model of a state and the Tokugawa model widened further during the late eighteenth and nineteenth centuries, as the Western states experimented with the introduction of various institutions of social control typical of modern nation-states. During the mid-nineteenth century, when the Western powers finally knocked at the gates of Tokugawa Japan, they appeared in the form of fully modernized nation-states with expansionist ambitions.

Only with this historical background in mind can we accurately imagine the magnitude of the psychological shock that the nineteenth-century samurai elite experienced when they encountered the superior military forces of the Western countries. The shogunate authorities were obliged to yield, however reluctantly, to Western demands, and samurai at all levels in the hierarchy attacked the shogun's concessions as a disgraceful compromise of Japanese sovereignty. Even though these protesting samurai accepted the realities of their immediate political situation, the fact that their country had had Western demands forced upon it appeared to them as a shameful blot on national pride. In spite of the shogunate's decentralized structure, two centuries of stable Tokugawa rule had created a distinct cultural climate and sense of collective identity. This climate included "romantic" intellectual movements such as Kokugaku (the "School of Native Learning", which claimed to find that "true" Japanese sensibilities had been most fully expressed in ancient classical literary texts). By recalling the Japanese literati to the glories of their cultural heritage in the face of foreign incursions, this nostalgic traditionalism provided fuel for a "nationalist" ethnic sentiment, which resulted in the paradoxical situation of a rise of "nationalism" before the establishment of a nation-state. ${ }^{11}$

"For a complex picture of the pre-modern formation of Japanese nationalism and its impact on the restoration in English, the reader is referred to: Albert M. Craig, Chōshü in the Meiji Restoration (Cambridge, MA, 1961); William G. Beasley, The Meiji Restoration (Stanford, CA, 1972); Conrad D. Totman, The Collapse of the Tokugawa Bakufu, 18621868 (Honolulu, 1980). In the context of intellectual history, see Masao Maruyama, Studies in the Intellectual History of Tokugawa Japan, trans. Mikiso Hane (Princeton; 
The Tokugawa shogunate's military incompetence in the face of the foreign powers provided the occasion for the most effective slogan of the nineteenth-century anti-shogunate movement, "Revere the Emperor and Expel the Barbarians"(sonno jöi). The legitimacy of the resulting new imperial government thus depended heavily upon its ability to protect Japan against Western encroachments. As growing numbers of samurai experienced the actual military power of the West at closer range, many of them recognized that the superiority of the Western political model was the key to advanced military capability. This rationale for introducing Western forms of government persuaded the Meiji oligarchs. Thus, the political mandate of the new government became the construction of a competent state, a "wealthy country with strong soldiers" (fukoku kyōhei) that could compete on an equal basis with the expansionist Western powers.

At the close of the Tokugawa regime, the shogunate signed various treaties with Western countries that were known to the Japanese as "unequal treaties". These treaties allowed the Western powers to hold extraterritorial consulate jurisdiction in Japan, and they restricted the Japanese government's power to set tariff rates. These treaties were in one sense products of the shogunate's political realism: the Tokugawa officials conducted their negotiations with the West in full awareness of the fate of their Chinese neighbors. In spite of the exigencies of Japan's political situation, the unequal treaties prompted intense popular indignation from their outset, as they were regarded as stigmata of national humiliation.

After the shogunate's collapse, the Meiji government was obliged to honor these treaties in order to keep the peace with the Western powers. As a result, treaty revision became one of the most urgent tasks of the Meiji leadership. The oligarchs embarked on a series of unsuccessful diplomatic attempts to revise these treaties. The clause regarding consular jurisdiction was a clear compromise of Japanese sovereignty; while the Meiji government also sought to increase the tariff revenue in order to gain a measure of fiscal stability. For the subsequent four decades, the task of modifying these unequal treaties became a recurrent bane of Japanese domestic politics. Since stagnation of any negotiations for revising the treaties was always interpreted as a sign of governmental incompetence in withstanding foreign power, this issue was a perpetual priority on the government's agenda. ${ }^{12}$

1974); H.D. Harootunian, "The Consciousness of Archaic Form in the New Realism of Kokugaku", in H.D. Harootunian (ed.), Japanese Thought in the Tokugawa Period, 16001868 (Chicago, 1978), pp. 63-105; H.D. Harootunian, Toward Restoration: The Growth of Political Consciousness in Tokugawa Japan (Berkeley, 1970); and Victor J. Koschmann, The Mito Ideology: Discourse, Reform, and Insurrection in Late Tokugawa Japan 1790 1864 (Berkeley, 1987).

12 Kenneth B. Pyle, "Treaty Revision and Self-Determination", in Kenneth B. Pyle (ed.), The New Generation in Meiji Japan (Stanford, 1969); Matsui Yoshio, "Jōyaku kaisei", in 
An interesting side-effect of the unequal treaties problem was its impact on the course of public discussion of citizenship matters. The Western countries made heavy demands on the Japanese for the modernization of law and jurisprudence so that they would have the benefits of a stable legal framework for commercial transactions in Japan. Thus the process of treaty negotiation compelled the Meiji leadership to recognize the importance of modernizing the judicial system in order to gain the confidence of the more advanced nations. Trade provided the most important impetus for introducing Western-style legal principles, including some provisions of civic liberty such as the protection of private property. This international constraint gave an unexpected twist to the further development of citizenship rights in the later period because, as we will see shortly, the Freedom and People's Rights Movement used the issue of treaty revision to gain leverage for its liberal claims.

\section{POPULAR ASPIRATIONS FOR THE RE-MAKING OF SOCIETY}

In sum, the Western imperialist intrusions in the 1850 s and 1860 s proved to be a catalyst for genuine social change. They reshaped Japan's contemporary political agenda by compelling the samurai elite to recognize the weaknesses and limitations of the Tokugawa state system. I use the term "catalyst" advisedly, however, because the West's impact was hardly sufficient to bring about a total systemic change of the sort exemplified in the Meiji restoration and subsequent state-making. Another incentive toward a major political overhaul was related to the fact that the political activists of the nineteenth century were aware of the serious domestic problems confronting the shogunate and local daimyo polities. Many local daimyō suffered deteriorating financial conditions at the same time that the frequency and intensity of peasant uprisings increased. Aoki Kōji's impressive catalogue of Tokugawa collective uprisings clearly indicates a significant rise in their frequency. ${ }^{13}$ The financial burden on the daimyo polities due to foreign threats only worsened the situation, because the main source of the revenue for the

Fukushima Masao (ed.), Nihon kindaihó taisei no keisei ge (Tokyo, 1982); Paul Heng-chao Ch'en, The Formation of the Early Meiji Legal Order (Oxford, 1981); Shimomura Fujio, Meiji shonen jöyaku kaiseishi no kenkyū (Tokyo, 1962).

13 Aoki Kojji, Meiji nōmin sōjō no nenji teki kenkyü (Tokyo, 1967), and Hyakusho ikki sōgó nenpyō (Tokyo, 1971). In post-war Japan, large-scale efforts to excavate local documents have produced remarkable advances in the study of Tokugawa collective uprisings. Drawing upon these documents, Aoki has catalogued conflicts which took place between 1590 and 1877. In English, see James White, The Demography of Sociopolitical Conflict in Japan, 1721-1846 (Berkeley, 1992). The reader is also referred to James White, "State Growth and Popular Protest in Tokugawa Japan", Journal of Japanese Studies, 14 (1988), pp. 1-25. For an overview of Tokugawa rebellions, see Ikegami and Tilly, "State Formations and Contention". 
daimyo governments continued to be the taxes paid by the agrarian population. The Tokugawa feudal taxation system was unable to extract sufficient revenues from the growing non-agricultural sector of the economy. Thus, the shogunate system was threatened from within by revenue shortfall, while external pressures from the West relentlessly exposed the systemic weaknesses of Tokugawa institutions. A sense of political futility engendered expectations at all social levels of radical change that reoriented subsequent public discussion regarding modern institution-building during the Meiji period.

The process that suddenly placed the emperor, previously a powerless figurehead, at the symbolic center of nineteenth-century Japanese political transition is a much-debated subject among historians. One partial explanation is the need of xenophobic nationalist movements for a new symbolic locus of loyalty and solidarity. This need, however, was insufficient by itself to explain the emperor's elevation to the status of a redeemer, a quasi-religious savior figure in the Meiji period. Recently, some English-speaking specialists in the field of Japanese intellectual history have placed heavy emphasis on the role of popular antiestablishment feeling, as it was expressed in a variety of grass roots discussions and collective uprisings in the nineteenth century. Writers such as H.D. Harootunian, Irwin Scheiner and George Wilson have emphasized the symbolic field of sentiments regarding the restoration shared, in part, by samurai political activists as well as by the common people. The utopian millenarian movements and outbreaks of popular hysteria that prevailed in the mid- and late nineteenth century (e.g. the peasants' yonaoshi rebellions, popular versions of kokugaku movements, frenzied dancing in the streets, ee janaika). ${ }^{14}$ The key term for these widespread sentiments was yonaoshi (literally, "a world made new"), that conveyed the hope that the old world order would be refashioned.

To be sure, these various popular movements did not have a common articulated political agenda, nor did they form organizational coalitions with political organizers toward the project of Meiji restoration. In this sense, their direct influence on the course of the restoration was limited. However, the samurai activists of various ranks in the pro-imperial movement also held a long-standing grudge against the Tokugawa political establishment. They were convinced that the state was governed by incompetents unworthy of their high positions. After all, in this status-oriented political system, higher as well as lower samurai experienced a feeling of political alienation in one form or another because of their hereditary social standings. It was in this socio-cultural climate that legitimation of the new imperial government as the fulfillment of people's aspirations for the total reconstruction of the world became a

14 Regarding yonaoshi and ee janaika in English, see George M. Wilson, Patriots and Redeemers in Japan: Motives in the Meiji Restoration (Chicago, 1992). 
politically viable strategy. In essence, the symbolic idioms of popular millenarianism provided preliminary cultural resources for the essential components of imperial symbolism in the Meiji period.

The creation of the emperor's image as an egalitarian social reformer, however, was not simply a cultural phenomenon, as some recent idealist historiographers suggest. The simultaneous codification of civil and political citizenship and the formation of imperial symbolism in the Meiji era was the result of complex interactions between the strategies of the ruling elites, opposition movements within the matrix of domestic institutional constraints, and international circumstances. I will now proceed to explicate some aspects of this hegemonic process.

\section{HEGEMONIC STRUGGLES, MOBILIZATION AND THE RISE OF QUASI-DEMOCRATIC DISCOURSES}

\section{KOGI YORON AND THE VULNERABILITY OF THE MEIJI OLIGARCHY}

If the slogan of "Honor the Emperor and Expel the Barbarians" represented the international mandate of the new government, another famous political catchword, "kögi yoron" ("Public matters determined by public discussion", meaning political participation) represented the Meiji regime's domestic imperative at the beginning of the era. This very popular slogan was immortalized in the popular mind by the Meiji emperor's famous "Five Article Oath" in 1868, his first public statement after the restoration. The emperor promised that his government would "seek wisdom from a broad range of people; everything in the government should be determined by public discussion". This motto emerged during the last stage of political struggle prior to the restoration; it implied a broader range of elite participation in the political process.

Though it has a progressive ring, this slogan encapsulated a realistic strategy on the part of the new Meiji regime, in that it recognized the potential instability of its political base. Since the restoration had been initiated by a faction of the ruling samurai class, the project rested on the maintenance of the solidarity of the anti-shogunate alliance. During the Tokugawa period, most of the regional daimy $\bar{o}$ lacked formal channels to insure that their opinions were incorporated in the policies of the central government. "Kögi yoron" also attracted lesser samurai who had been estranged from the political process. Therefore, the possibility of having some impact on national policy-making was very attractive to samurai at all social levels. In other words, "kögi yuron" was an ideological device for the newly emerging government to distinguish itself from the discredited Tokugawa regime as well as to foster solidarity among elite participants with divergent political and social interests. 
Since it was carried out by a faction of the samurai class itself, the Meiji restoration reflected the internal struggle of the samurai class from its beginning. The large number of Meiji leaders who were assassinated during the early years of the regime mirrors the violent climate of the time. The actual work of the restoration was carried out by a loose alliance of assorted social forces: (1) a core group of samurai leaders from Chōshū, Satsuma and a few major allied domains including Tosa and Hizen; (2) other daimyo domains that were affiliated with the anti-shogunate forces but excluded from the core group; (3) a number of grass roots political activist groups (led for the most part by wealthy farmers or $g \bar{o} n \bar{o},{ }^{15}$ and lesser landed samurai or gōshi) ${ }^{16}$ and (4) a small group of Kyoto courtiers. After a few battles between the shogunate's opponents and supporters in 1868, which ended in the defeat of the shogunate's side, ${ }^{17}$ the next political task was the implementation of the insurgents' initiatives for the construction of the modern state system.

Although the leaders of the first group were often labeled as Meiji oligarchs, in the early stages they did not have secure control of the country. Their connections with the emperor were often disrupted by the fourth group, the Kyoto courtiers. In addition, other feudal domains retained their private military forces. The abolition of the feudal daimy $\bar{o}$ domain (han) system in 1871 came about through concentrating the allied military forces of Chōshū, Satsuma and two other major domains under the aegis of the central government. However, since the daimyo houses were struggling with heavy financial debts, the government seized the opportunity to purchase political advantage. ${ }^{18}$ In exchange for surrendering their feudal prerogatives, the former daimyo lords were handsomely rewarded with government bonds and new titles of honor and prestige in the emperor's court, in spite of their complete exclusion from the circle of Meiji oligarchs. After the dissolution of the han, the former samurai vassals who had been hereditary employees received some partial compensation in the form of government bonds. However, sporadic local uprisings of former samurai continued to trouble the new regime, which was also beset by its own internal power struggles within the oligarchy (i.e. primarily, though not exclusively, within the core group of the leadership).

is Since the gono had been village leaders during the Tokugawa period, and had often been appointed as village officers, they had absorbed some aspects of samurai culture.

${ }^{16}$ A status category ranking immediately below formal samurai status. Since goshi had not been formally employed by the daimyō, they were not samurai vassals, although they claimed descent from families of samurai status.

17 Shimoyama Saburo, "Boshin sensō to ishin seiken", in Shimoyama Saburo (ed.), Iwanami koza Nihon rekishi, 14 (Tokyo, 1975).

18 Regarding the financial crisis of the han polities, see Gotō Yasushi, "Shizoku hanran to mishă sojō", in Shimoyama, Iwanami kōza Nihon rekishi, 14, pp. 271-281. 


\section{CONSCRIPTION AND THE NEW NATIONAL ARMY}

In spite of this vulnerability, or more precisely because of it, the central leadership could not slow the pace of state institution-building, for one pressing reason. Unless the core group built up direct arms of social control to replace preexisting feudal structures, they could not effectively govern the country as a whole. Furthermore, the construction of a strong and soundly financed state that could hold its own against the West was the political charter of the new regime.

In order to introduce the requisite institutional reforms and innovations, the most urgent task for the Meiji regime in its early years was the mobilization of a recalcitrant citizenry for the hard labor of modern nation-building. The leaders needed to stimulate participation in the creation of a powerful Westernized state supported by responsible koku$\min$ (citizens). The concepts of political participation, freedom (jiy $\bar{u}$ ) and egalitarianism were necessary tools for consciousness-raising among those sectors of the population that had been excluded from the political process under the shogunate. From its inception, the Meiji era saw itself as the antithesis of the backward, feudal, isolationist and anti-scientific Tokugawa era. In his Five Article Oath in 1868, which set the tone for the new era, the Meiji emperor portrayed himself as the embodiment of enlightenment and democracy. Quasi-democratic discourse appeared even more prominently in the 1872 decree instituting national conscription, which included the following egalitarian rhetoric:

In our ancient system, people from all over the country became soldiers [. . .] when they were discharged [from military duties] to home, these soldiers resumed their places as farmers, craftsmen or merchants. These soldiers were different from the so-called samurai of the later period who carried two swords and arrogantly confiscated the produce of others' labor. [. . . ] Now the samurai's stipends are decreased and they are allowed to dispose of their swords; ${ }^{19}$ people from all four status ${ }^{20}$ groups are [equally] gaining the rights of freedom. This is the way to even distinctions between upper and lower classes, and to equalize people's rights; this is the foundation for the integration of the military and the agricultural [sectors ... .]. If the country were overwhelmed by a disaster, [all] people would be also affected in part. Therefore, the people should know that their fundamental protection against personal disaster lies in defending the country against catastrophe $\left[\ldots . .{ }^{21}\right.$

19 A few years later, the samurai stipends were terminated, and the carrying of the traditional swords was prohibited. At this stage, however, the abolition of the samurai's status and privileges was still incomplete.

${ }^{20}$ Samurai, farmers, craftsmen and merchants. These four groups comprised the feudal status categories which defined the samurai as rulers and all others as subjects.

${ }^{21}$ Chōhei kokuyu, reprinted in Nihon kindai shisō taikei, 4: Guntai to heishi (Tokyo, 1989), pp. 67-68. Regarding the history of conscription, the reader is referred to Matsushita Yoshio, Chōheirei seiteishi (Tokyo, 1981); Fukushima Masao, "Gunji kikō no 
As this example demonstrates, the Meiji government stirred up popular expectations that society would be reborn at the emperor's behest. All status groups would henceforth be equalized, and government policies would be determined by kōron ("public discourse"). However, even with considerable persuasion, the peasantry generally refused to cooperate with the Meiji government. Under the Tokugawa regime, the non-samurai population had grown accustomed to the notion that military service was a class-bound obligation reserved for the samurai. A poorlyworded passage in the 1872 decree which described military duty as analogous to ketsuzei (blood tax) - "[W]esterners call this (national conscription) blood tax, because people contribute their own blood to their countries" - generated enormous anxiety in peasant households. Many parents interpreted the phrase to mean that their sons' blood could be taken by the government as new taxes; some peasants who were dissatisfied with the conscription system and the government's modernization policies in general went to the length of organizing ferocious ketsuzei ikki (literally, "blood tax revolts"). The blood tax revolts began in two prefectures in March 1873, and then spread to seven other prefectures as well as Kyoto province in the same year. These peasant revolts not only expressed opposition to the program of conscription but also to many other modernization projects proposed by the government (such as the introduction of school systems) that forced the peasants to change their ways of life.

In addition to the ketsuzei ikki, the Meiji authorities also had a major problem with widespread draft evasion. The Minister of Defense described the deplorable situation in 1881, in his official report to the government: "They (twenty-year-olds) file for exemption by taking advantage of inaccurate documentation in family registration, or simply run away in order to escape conscription". The minister added that "according to last year's data, there were $10,360^{22}$ runaways avoiding the draft". Many young men simply failed to appear for their draft physical examination, and returned home after the date for the examination (or sometimes a few years later).

It is difficult for Westerners to picture the extent of draft evasion during this early Meiji period because of stereotyped images of aggressively well-drilled Japanese soldiers in movies and documentaries of World War II. It is true that the concept of kokumin ("citizen"), of a person who is the subject both of rights conferred by and obligations to a government, was utterly alien to the nineteenth-century Japanese.

kensetsu", in Fukushima Masao (ed.), Nihon kindai hö taisei no keisei (Tokyo, 1981); Oishi Shinzaburō, "Chôhei sei to ie", Rekishigaku kenkyū, CXCIV (1956).

2 Total figure, according to the army minister's report (rikugunkyd). Oyama Iwao served as army minister in 1881. Chöhei ihi ni tsuki kengi, reprinted in Nihon kindai shiso taikei 4 , p. 119. A number of handbooks describing ways to evade the draft were published during this period. 
The government's use of the rhetoric of freedom and citizenship, however, had an unforeseen side-effect, namely an illusory anticipation of social reforms. This manipulation of quasi-democratic idioms in turn shaped the direction of public discussion in subsequent decades.

\section{THE LAND TAX REFORM AND PEASANT UPRISINGS}

As soon as political unification was completed under the new government, the introduction of a system of national taxation then became the next priority. The Tokugawa tax system had been largely decentralized; there was no national office of revenue collection, nor did the daimyō pay taxes to the shogun. In order to finance the various projects of the central government, the Meiji oligarchs confronted the necessity of centralizing and streamlining the tax system through the conversion of taxes in kind to cash taxes. Moreover, they had to overcome the obstacles posed by feudal property rights. As a result, the nationalization of the Japanese taxation system simultaneously involved the legal codification of property rights as well as the registration of the owner of each piece of taxable real estate.

After a period of prolonged discussion within the Ministry of Finance, the ministry promulgated in 1870 a nation-wide plan for land tax reform. The plan provided for land surveys, distribution of certificates of ownership to farmers and a standard taxation rate of 3 per cent of the cash value of each plot of land. The farmers were generally cooperative with the land survey itself, in so far as it formalized their private ownership of land. At the same time, however, they discovered that the actual tax rates were at least as high as those of the Tokugawa period. The peasantry would have preferred that the new government devote its energies to yonaoshi - a popular slogan of peasant rebellions at the end of the Tokugawa period - i.e. freedom from oppression and, most importantly, a lighter tax burden. The newly established government with its unstable financial basis did not have any other major sources of tax revenue other than the agricultural sector. After 1872 the government accelerated efforts to implement a tax reform project that involved the land survey and decisions regarding land prices as the basis for calculating individual tax schedules. ${ }^{23}$

According to Aoki Kōji's catalogue of collective uprisings in the Meiji period, ${ }^{24}$ the number of peasant $i k k i$ (collective actions against the

${ }^{23}$ The normalization of land as private property confronted two obstacles: the abolition of the samurai's feudal privileges, and the identification of sharecroppers and landlords who were responsible for payment of land taxes. Regarding these complex issues, see Niwa Satoru, "Ryōshusei no kaitai to tochi kaikaku", in Rekishigaku kenkyūkai and Nihonshi kenkyũkai (eds), Köza nihon rekishi (Tokyo, 1985), p. vii; Niwa Kunio, Chiso kaisei to zaisei kikō no kakuritsu (Tokyo, 1981); Nakamura Satoru, "Ryōshusei no kaitai to tochi kaikaku", in Rekishigaku kenkyūkai and Nihonshi kenkyükai (eds), Kóza Nihon. 2s Aoki, Hyakushó ikki. 
authorities) peaked between 1868 and 1872, when the collapse of the Tokugawa regime created a power vacuum in outlying areas. However, even after the Meiji government was established, the number of peasant uprisings rose in response to the proposed tax reform (chiso kaisei). There were 56 revolts in 1873, 21 in 1874, 19 in 1875, 28 in 1876, and 48 in 1877. In particular, in December 1876, the most extensive ikki affected four provinces (Ibaragi, Mie, Aichi and Gifu), in which 57,000 peasants were eventually arrested. ${ }^{25}$ The peasant $i k k i$ were especially threatening to the Meiji government because former samurai who were alienated by the new policies often organized violent revolts almost at the same time.

Minister of the Interior Ōkubo Toshimichi, at that time the most influential politician, warned the government of the gravity of the situation in 1876: "If the government does not take measures to relieve the unbearably heavy burdens on the peasants, not only the farmers, but the general public will voice angry complaints against the government. The situation will surely become uncontrollable". ${ }^{26}$ On the other hand, the government imposed harsh punishments in order to control the uncooperative and rebellious elements of the population. The government officials also recognized that it was preferable to induce voluntary collaboration with the tax reform than to punish non-compliance. In response, the government instituted significant reductions in national and local tax rates. With the help of incidental inflationary economic measures that reduced the burden of cash tax payments, the land survey and tax reform were completed. The abolition of feudal land tenure and the concept of land as private property were firmly institutionalized in the process.

\section{THE REVOLT OF THE FORMER SAMURAI}

In addition to the peasant $i k k i$, revolts led by former samurai added to the domestic problems of the new regime. To list the major ex-samurai uprisings during this troubled decade: the rebellion in Saga province (1874, 11,820 participants), led by Etō Shinpei, the former Minister of Justice; the Akizuki Uprising in Fukuoka Province (1876, 230 participants); Jinpüren Uprising (also 1876, 193 participants); and the Hagi Uprising of Chōshū Province, led by former Councillor Maebara Issei. The rebellion of General Saigo Takamori (1877), which mobilized troops of angry former samurai in the Satsuma domain $(23,000$

25 For an overview of peasant rebellions of this era, see Gotō, "Shizoku hanran to nōmin sōjō". For an account of the complex internal workings of these peasant uprisings against tax reform, see William Kelly, Deference and Defiance in Nineteenth-Century Japan (Princeton, 1985), pp. 173-204.

${ }_{26}$ A letter from Ókubo to Prime Minister Sanjo Saneyoshi, 27 December 1876, in Okubo Toshimichi bunsho (Tokyo, 1969), VII, p. 439. 
participants), represented the most serious organized revolt against the Meiji regime. ${ }^{27}$ After several months of fighting, however, the government army, consisting mostly of draftees, defeated Saigō's ex-samurai troops. With Saigo's death, organized samurai resistance to the new government dwindled away.

Comparative sociological literature regarding the rise of Western citizenship rights has usually depicted the resistance of the feudal landlord class and resultant peasant rebellions as conservative forces that often inhibited the expansion of citizenship rights. Given the weakness of the urban bourgeoisie's organized power, how can we understand the fact that Meiji Japan achieved a significant degree of civic and political rights? And why did the conservative Japanese ex-samurai rebellions not succeed together with the simultaneous peasant movements?

As a step toward answering this question, I will briefly summarize the reasons for the government's ability to contain these samurai uprisings, despite the fact that they occurred at the same time as the peasant revolts. Samurai resistance movements were largely organized by individuals who had been defeated in the internal power struggles within the Meiji leadership core. Those who had originally belonged to the pro-shogunate domains (such as Aizu) did not have the resources to lead rebellions. Furthermore, no former daimyō lord led or joined any of these ex-samurai uprisings. ${ }^{28}$ For example, in the case of Saigō's rebellion, Lord Shimazu (the former daimyō of Satsuma domain) opposed the revolt. Had Lord Shimazu collaborated with Saigō, the scale of the rebellion might have expanded considerably. With the abolition of the han system in 1871, and the absence of the ex-daimyo lords' personal endorsement, disaffected former samurai could not draw upon the organizational resources of the daimyo polities. In the meantime, some ex-samurai put their military skills to work in local police forces or the new national army; others accepted employment in elementary schools, while the more fortunate secured offices in the expanding bureaucracy of the new central government. ${ }^{29}$ In sum, the government took advantage of the polarization of the ex-samurai, at the same time that the ongoing institution-building of the modern state helped to weaken the old feudal networks of patronage and loyalty.

${ }^{27}$ Saigo had been considered the most prominent military hero of the Meiji restoration. 28 The exception was the abortive anti-government coup d'état in Kurume domain in 1871. In this case, the former daimyo lord was put under house arrest, and the government arrested 339 other participants.

${ }_{29}$ The lesser samurai who received a small sum in government bonds often moved down the class ladder to join the numbers of the powerless urban poor, because they had few assets other than their hereditary income from the daimy $\bar{o}$. The government introduced various employment programs for the ex-samurai, but none were very successful. For an overview of the process of samurai dissolution, see Hidehiro Sonoda, "The Decline of the Japanese Warrior Class", Japan Review, I (1990), pp. 73-111. 
Secondly, the fact that rebellious former samurai did not form systematic alliances with the peasant movements greatly benefited the Meiji government. The samurai uprisings were relatively small and localized compared to the wider scale and greater frequency of peasant movements. For example, no samurai revolts can compare with the size of the 1873 rebellion in Fukuoka province, which mobilized 300,000 peasants. The two types of anti-government movements never made extensive contacts with each other. The two classes had different social goals and interests: while the ex-samurai who lacked land tenure did not share the peasantry's intense concern with tax rates on real estate, their reactionary agenda - such as reinstatement of feudal status privileges had no appeal for the peasantry. ${ }^{30}$

The failure of conservative ex-samurai resistance movements did, however, set the stage for more ideologically charged popular movements for citizenship rights. Movements of the latter type offered the former samurai a reasonable alternative to armed opposition. Though terrorist violence itself was a frequent occurrence, as indicated by Ōkubo Toshimichi's assassination in 1878, the cessation of organized military resistance made the trend toward defeudalization irreversible. The former samurai's political agenda - the protection of feudal privileges - had lost all relevance. The Meiji oligarchs had strengthened their power base by eliminating powerful competitors while simultaneously expanding and confirming the institutional arms of social control which characterize the modern state. Thereby they significantly increased their independence from the social groups to which they had originally belonged, or with whom they had been allied. The general public was keenly aware of the political significance of this increased autonomy. Opposition spokesmen began to refer to the government as "bureaucratic despotism" (yüshi sensei). Although the Meiji restoration had been carried out under the banner of sonno ("Revere the emperor"), with the quasidemocratic slogan of kogi yoron, it was not the emperor but the officials who actually ruled the country. Opposition to bureaucratic despotism thus emerged as the common purpose connecting a variety of protest groups. ${ }^{31}$

${ }^{30}$ The sharp conflict of interest between the samurai and the peasantry was the locus of class struggles throughout the Tokugawa period. In pre-modern Japanese history, it was always the agricultural villages rather than the cities that had the organizational resources for mobilizing opposition against the feudal samurai powers. Under the Tokugawa system, the villages were collectively responsible for paying the grain tax to the daimyo lords. The villagers were allowed to retain some degree of self-government while the samurai vassals who had been landed lords in the previous period were forced to reside in the castle cities of the daimyo.

${ }^{31}$ Ikai Takaaki, "Jiyū minken undo to sensei seifu", in Rekishi gaku kenkyükai and Nihonshi kenkyükai (eds), Köza, Nihon rekishi 7 kindai 1 (Tokyo, 1985), pp. 261-268; Tōyama Shigeki, "Yüshi sensei no seiritsu", in Meiji ishin (Tokyo, 1973; 1st ed. 1959). 
The Jiyū Minken Undō or Freedom and People's Rights Movement ${ }^{32}$ originated in the political split which occurred in the ranks of the Meiji government in October 1873 over the question of armed intervention in Korea. Itagaki Taisuke and Gotō Shōjirō, two former samurai politicians from Tosa domain, and Saigo Takamori of Satsuma domain resigned from the government following rejection of their proposal for military invasion. While Saigo eventually opted for armed rebellion, Itagaki and Goto took a different path. After they resigned from office, they submitted an open petition in 1874 , demanding the establishment of a national assembly. They subsequently organized political associations in a number of regions promoting their cause. Itagaki and Gotō's initiative, one of the earliest calls for a popular assembly, inspired a number of grass roots activists. It was the first modern, nation-wide civil rights movement to generate sufficient public discussion as to have a significant influence on the course of Japanese state formation.

Though their philosophical claims and idioms were democratic in their inspiration, Itagaki and Gotō's actual program for a national assembly at this stage did not differ appreciably from the elitist version under discussion within the Meiji leadership circles. Japan's first freedom movement was headed by former samurai with an aristocratic sense of mission, obligation and autonomy. I have elsewhere described the Japanese samurai's cultural legacy with the term "honorific individualism". ${ }^{33}$ An elitist sense of self-determinism developed within the warrior culture of medieval Japan as a by-product of a feudal form of land tenure. This initial "honorific individualism" was transmuted into a more state-centered version during the Tokugawa period through the bureaucratization of samurai vassals. The legacy of transfigured honorific individualism served in turn as a resource for cultural change when it was effectively connected to a social goal. This process was facilitated in the early Meiji era when politicians drawn from the class of former samurai reinforced the movement for political freedom by infusing progressive ideals into nationalist sentiments. Itagaki himself later elaborated on his standpoint as "freedom and individualism balanced by the concept [and needs] of the state". He also called it "advanced individualism (kötō kojin shugi"). ${ }^{34}$ However, having been increasingly impoverished through their deprivation of hereditary income,

32 There is no precise definition of Jiyü minken undō, as the term included a miscellany of loosely organized groups interested in promoting citizenship rights. In Japanese historical scholarship, popular movements in the period between 1874 and the early 1890 s are usually lumped together as Jiyũ minken undō, or Freedom and People's Rights Movements. ${ }^{33}$ See Eiko Ikegami, Taming of the Samurai, pp. 349-360.

34 Ohashi Tomonosuke, "Meiji kokka kensetsu ni okeru hō-kokka kan no sōkoku", in Fukushima, Nihon kindai, p. 416. Regarding the ex-samurai's contribution to the movements, see Tỏyama Shigeki, "Jiyũ minken undō ni okeru shizoku teki yōso", Jiyū minken: rohshü nihon rekishi 10 (Tokyo, 1973). 
and lacking landed properties, the former samurai were not sufficiently powerful by themselves to direct the course of the freedom movements. (The urban middle class had not yet emerged as a socio-political force at this stage.) Consequently, the adherence of gōnō, or well-to-do farmers, proved to be crucial to the movements' success.

The gōno provided local leadership for the freedom movements. This prosperous farming class had served as village officers under the Tokugawa system and had coordinated the activities of village selfgovernment. Because of the necessity of communicating with samurai administrators, the gōno were usually literate, and had partially absorbed the samurai's disciplinary culture as well. Since they were commoners, however, they were excluded from formal political participation. The separation of the samurai from land tenure under the Tokugawa meant that unlike the English landed gentry, individual samurai could not turn themselves into entrepreneurial landlords and benefit from the development of commercialized agriculture that flourished during the nineteenth century. Rather it was the gōno in the economically advanced regions that took advantage of the commercialization of Japanese agriculture.

The ideology of freedom and human rights was a catalyst for the combination of different social forces - such as the former samurai and wealthy farmers - whose social and economic interests were not identical, but who were equally outsiders to the Meiji regime. A staggering amount of Western technology and know-how poured into Japan during the first decade of the Meiji period. Intellectuals such as Fukuzawa Yukichi, who regarded feudalism as his ancestral enemy, and Nakane Chōmin, a disciple of Rousseau, had actively disseminated British and French philosophies of political liberalism. Popular circulation of journals of opinion, as well as the growing appeal of public political rallies neither of which had existed during the Tokugawa period - facilitated nation-wide public discussion of citizenship rights. After a decade of "civilization and enlightenment (bunmei kaika)", the idiomatic repertoire of freedom and democracy became available to anyone with a cause to advertise.

The Freedom and People's Rights Movements thus represented different kinds of local groups comprising former samurai, wealthy farmers and emerging urban intellectuals. Since the early 1870 s, the gōno had sponsored a number of local voluntary associations. In many regions, the gōnō organized other provincials, including lesser farmers, into local "study groups" in which the young enthusiasts absorbed Western political ideologies. Some of these village study groups discussed such topics as the American and French revolutions, and read translations of Rousseau, Spencer and Mill. ${ }^{35}$ Many of these local groups were involved in miscel-

${ }^{35}$ Emura Eiichi, Jiyū minken kakumei no kenkyū (Tokyo, 1984), pp. 35-40; Irokawa Daikichi, Ei Hideo and Arai Katsuhiro, Minshü kenpō no sōzō (Tokyo, 1970). 
laneous programs for local improvement, such as the promotion of regional industries and poor relief. The emergence of these grass roots organizations was triggered by opposition to the government's top-down implementation of tax reform; new regional policies stimulated the political consciousness of village populations. In the late 1870 s, hundreds of these local groups evolved into centers of regional networks for organizing populist agitation for freedom rights. These networks were loosely connected to central organizations. ${ }^{36}$

By 1880 , with the expansion of local associations, the non-samurai participants increased their influence within the movements. For example, an 1879 rally in Okayama prefecture in support of a national assembly specifically rejected a proposal to select representatives from the respectable local former samurai because "eighty percent of the leaders were commoners". The resultant public discussion was populist in sentiment as well as nationalist:

Our beloved thirty-five million brothers! If you share our feelings and emotions, why do you not take a stand and demand a national parliament? Why do you not aspire to the expansion of the people's rights? Why will you not work to increase our country's power? (Public statement of the Okayama prefecture council, 1879)

The active focus of the local Freedom and People's Rights associations was the organization and submission of petitions and proposals for a national assembly. Though this may seem like an irenic strategy, it generated stormy debates that presented a real threat to the stability of the Meiji government. In fact, some participants openly advocated that "the authoritarian government should be overthrown". On a previous occasion, some former samurai in the Freedom and People's Rights Movement had joined Saigō Takamori's military rebellion. There was no guarantee that movements that were peaceful in their inception would not evolve into violent anti-government protest.

\section{THE LOGIC OF THE FREEDOM AND PEOPLE'S RIGHTS MOVEMENT}

Petitionary agitation for a parliamentary system reached its peak around 1880 , accounting for 85 formal petitions (out of a total of 130 between 1874 and 1881) submitted to the government. The petition movements were loosely coordinated by a national front organization, Kokkai Kissei Dōmei or "Federation for the Realization of a National Assembly", established in March 1880 . The participants in the petition movements between 1874 and 1881 (i.e. signatories) totaled 319,000 individuals. Associations for petition movements existed in all forty-six prefectures. 
The drafters of most of these documents emphasized the emperor's promise of popular participation in politics. Many petitions cited the emperor's famous "Five Article Oath" of 1868, in which he had pledged to allow open public discussions of official policy. In addition, the petitions referred to the subsequent emperor's pledge in 1874 that the government would move in the direction of establishing a constitutional polity. Although Western notions of civic and political citizenship rights as inherent in human beings were well known to these populist leaders, only 13 per cent of these petitions actually drew upon Western liberal political ideologies to legitimate their causes. The typical logic of these petitions is illustrated by the following excerpt:

We, the people, seek the right to participate in politics. The government should respond immediately to our demand by accepting the people's right of political participation. Remember the fact that our demand is in accordance with the emperor's Five Article Oath announced at the beginning of the Meiji era, which was then confirmed and extended in His Majesty's announcement in 1874! (written by a local activist Ōtsu Junichirō in 1880) ${ }^{37}$

From the outset of the Meiji restoration, the emperor had always been a symbol of progress; he had been the human representative of the end of feudalism and the construction of a new nation. He was an icon of modernity and enlightenment as well as of tradition and continuity. Though the emperor was supposedly the object of every citizen's political allegiance, as a person he was never in the center of political decision-making in the Meiji government. Because of his marginal position and dual symbolic power, the emperor was exempt from populist criticism and could be invoked as a symbol for change by every political camp. The fact that the oligarchs did not move to fulfill the emperor's promise in the earlier period was adduced as proof that they did not embody the imperial will. This criticism proved to be a powerful weapon against that part of the oligarchy that could not legitimate its hegemony. Though some anti-imperial republican discourse surfaced from time to time in the local populist movements, most freedom activists preferred a pro-imperial strategy that could not readily be rejected by anyone, the oligarchs included. The passionate discussions that were generated by the Freedom and People's Rights Movements both reflected and fueled a blazing patriotism, and these nationalist sentiments were also shared by the oligarchs. While the oligarchy stressed one component of nationalist logic by emphasizing that popular contentment could not exist apart from a sense of pride in the country, the civic activists argued that promotion of popular rights was the necessary basis for a strong state that could compete with the Western countries. The foundation of a working compromise was laid on this basis, because the oligarchs

3727 March 1880, in Haraguchi Tekeaki (ed.), Meiji jüsannen zenkoku kokkai kaisetsu genröin kenpakusho shüsei (Tokyo, 1956). 
themselves came to recognize the need for a modern constitution that would define the legal connections between the emperor and their executive power.

A second important line of argument that was frequently used in popular petitions was the claim that popular political participation was necessary for national solidarity. This argument was closely connected to the political situation around 1880 . The Meiji leadership group was burdened at that time by two major problems, fiscal deficits and the continued existence of the unequal treaties. The expansion of the project of modern nation-building had severely strained the finances of the Meiji government. Although the introduction of a national taxation system was nearly complete, peasant uprisings in opposition to the tax rates were an ongoing problem. On the international front, negotiations for treaty revision had broken down. The leaders of the freedom movement argued forcefully that popular political participation was essential to overcome these two problems. For example, one petition asserted:

Although the people have spirit and energy, unless the state gives them proper outlets for their energy, their sincere and loyal spirit will be wasted. As we witness the deterioration of the state's finances, we, the people, can only deplore the situation. We cannot do anything [to change it]. Knowing that the revision of the unequal treaties is not yet realized, we can only feel a sense of intolerable national humiliation [. . . ] Isn't it time to get rid of old customs, and to revise the outdated legal system? Is this not a time of national crisis that requires the entire reconstitution of our country? If so, why not let the people participate in politics on an equal basis and allow them to debate the future of our nation and our fiscal system $?^{38}$

From the early stages of the regime, the Meiji leadership realized that unless the Japanese legal systems were modernized (= Westernized), Japan could not join the company of "civilized nations". Legal experts from Western countries explicitly pointed to the inadequacy of Japanese jurisprudence and judicial systems as a reason for retaining the provisions of the unequal treaties. Throughout the first two decades of the Meiji period the Japanese government repeatedly negotiated with Western countries to revise the treaties, but all such efforts were in vain.

As an illustration of the stalemate, the German ambassador asserted in 1881 that because of the backwardness of the Japanese legal system, foreigners should be exempt from prosecution in Japanese courts unless the courts appointed Western judges or required the Japanese judges to take bar examinations in the West. ${ }^{39}$ The Japanese foreign minister Inoue Kaoru explained to the German ambassador that the country had

${ }^{38}$ Haraguchi, Meiji jüsannen, pp. 6-7.

${ }^{39}$ Matsui, "Jūyaku kaisei", in Fukushima, Nihon kindaihō, p. 228. See also F.C. Jones, Extraterritoriality in Japan and the Diplomatic Relations Resulting in Its Abolition, 18531899 (New Haven, 1931), pp. 77-78. 
to cope with the "unruly atmosphere" caused by the Freedom and People's Rights Movements that demanded constitutional polity and the abolition of extraterritorial jurisdiction. Since the overwhelming majority of Japanese citizens as well as the press favored the revision of unequal treaties, Inoue observed that the government did not dare to reject the populist demands, even though legal reforms were insufficient by Western standards. ${ }^{40}$ However, having acquired a keen awareness of the centrality of legal theory as well as practice in Western society, the government officials stepped up efforts toward judicial Westernization. Many foreign legal scholars were invited for consultation, while those Japanese who had studied abroad shared the benefits of their legal education. ${ }^{41}$ It was in this context that the Meiji government came to accept the necessity of a modern constitution.

\section{THE REACTIONS OF THE GOVERNMENT}

Patriotic activism on the popular level drew an immediate response from the Meiji oligarchy. On the one hand, the government devised a series of harsh repressive measures restricting freedom of expression, including banning certain publications, and limiting public rallies. However, the unprecedented intensity of popular demand for a parliament between 1879 and 1881 inhibited government sole reliance on repressive measures. Even a conservative oligarch such as Iwakura Tomomi came to regard the establishment of a national parliament as an inevitable concession, given the emperor's promise. ${ }^{42}$ For Iwakura, the enthusiasm of the Freedom and People's Rights Movements was reminiscent of "the eve of the French Revolution".

On 12 October 1881, an imperial rescript was promulgated, calling for the establishment of a national assembly in 1890. By setting a definite date for the opening of the national parliament, the government took some control over the direction of public debate. This government pledge of 1881 deprived the Jiy $\bar{u}$ minken movements of their primary issue. ${ }^{43}$ After 1881, the focus of public debate shifted to discussion of the content of Japan's first modern constitution, which ultimately came down to the question of the most desirable political system for Japan. In 1882, the

${ }^{20}$ Matsui, "Jōyaku kaisei", p. 228.

"During the early Meiji period, the influence of French law was predominant in the fields of Japanese commercial, family and criminal law. However, British and German legal systems were also intensively studied at this time.

${ }^{42}$ Letter to Sanjō, December 1879. Reprinted in Iwakura Tomomi kankei bunsho, I, p. 94.

${ }^{43}$ Around this time, the influential liberal progressive politician Okuma Shigenobu was expelled from the government. The remaining members then agreed among themselves to base the draft constitution on the Prussian model, in order to strengthen the power of the monarchy. The reader is referred to Hirano Takeshi, "Kenpo no seitei", in Fukushima, Nihon kindaihö taisei, p. 283. 
Meiji government sent a delegation of government officials to Europe under the leadership of Itō Hirobumi, to investigate the structures and functions of European political institutions in preparation for establishing a contemporary Japanese constitution. Itō was convinced that the Prussian model of authoritarian polity, rather than the more liberal British and French patterns, was most suitable for Japan. Itō's "finding" itself was hardly unpredictable; even before the delegation's visit to Europe, the variations in European political systems were well known to the Japanese intellectuals . Although Itō's report added little new information, it confirmed the Meiji regime's authority and initiative as the planning center for a new constitutional polity. Thus Itō's visit was instrumental for the Meiji government's attempt to regain control of theoretical discussions of a draft constitution. During this period, a number of grass roots activists also produced their own versions of a model constitution. However, these populist activists were completely excluded from the small closed circle of the government committee that drafted the official constitution.

In the interim, the central political associations of the Jiy $\bar{u}$ minken distanced themselves from local radical populist movements (exemplified by several violent uprisings such as Fukushima (1882), Gunma (1884), Kabasan (1884) and Chichibu (1884-1885)). ${ }^{44}$ In differentiating themselves from violent grass roots uprisings that had an anti-government orientation, the more moderate leaders attempted the formation of organized political parties in preparation for imminent political transition. Thus, the government's concessions in 1881 divided and weakened the popular movements, and forestalled further expansion of the Freedom and People's Rights Movements.

\section{SPIRITUAL NATIONHOOD VS. PRACTICAL NATIONHOOD}

In the lengthy process of constitutional debate, the leaders of Meiji Japan placed increasing emphasis on the so-called kokutai or myth of continuity which described 'Japan's distinctive national identity. The term kokutai connotes the spiritual component of nationhood, based upon the emperor's genealogical descent from the gods. The term was vaguely used in contrast with seitai (political form), which included the methods and structures for exercising sovereign power. While the latter might change its form from time to time, the former represented a static principle of continuity of national identity. Having observed the magnitude and intensity of populist enthusiasm, the conservative members of the government believed that national solidarity depended on the symbolic force of the emperor's person as the supreme embodiment of

4 Regarding these incidents, see Roger Bowen, Rebellion and Democracy in Meiji Japan: A Study of Commoners in the Popular Rights Movement (Berkeley, 1980). 
national distinctiveness. The process of drafting the constitution reflected this conservative position in so far as it replaced the term kokumin (citizens) in the text with the term shinmin (subjects), in an effort to stress a distinctive national identity predicated on kokutai.

The ideology of kokutai, especially its distinction from seitai, was a uniquely nineteenth-century product. Although the imperial myth has been a part of Japanese culture for centuries, it has not always been particularly politically powerful. During the several centuries preceding the Meiji era, Japan was ruled by a professional warrior class whose sense of Realpolitik was closer to a Hobbesian political outlook than to mythological or moralistic perspectives. The imperial myth as a political symbol resurfaced along with nationalism in nineteenth-century radical groups, such as the Mito school. It was in this context, that the term kokutai emerged for the first time in political discourse. This development, however, did not imply that the mythical authority of the emperor linked to the idiom of kokutai was widely accepted by the population at large during the late nineteenth century. Most of the Meiji oligarchs were also thoroughly realistic politicians who survived the revolutionary turmoil of the restoration, and the emperor was a more or less convenient tool for them to use in their opposition to the shogunate. The reason that conservative oligarchs, such as Iwakura Tomomi, and his protégés, Inoue Kowashi and Kaneko Kentarō, began to differentiate between the "unchanging" kokutai and "transitory" seitai at this stage in the 1880s had to do with their recognition that some degree of accommodation to populist demands and Western pressure was unavoidable. In particular, Inoue and Kaneko were not the kind of conservatives who wholeheartedly subscribed to the myth of the emperor; they were intellectuals who had a very good knowledge of Western legal systems. By introducing the distinction between kokutai and seitai, however, they attempted to reconcile the inevitable modifications of seitai, such as the introduction of a constitutional monarchy and parliamentary politics, with the notion of a timeless principle of national continuity embodied by kokutai. The theoretical distinction between these two was employed in order to "naturalize" Western political institutions and ideas while firmly upholding a sense of continuity with tradition and a conceived unique national identity. ${ }^{45}$

This utilitarian approach of engineering a new national identity was also evident in Itō Hirobumi's attitude which played a central role in the process of drafting the constitution. Itō argued that the lack of a Japanese religious equivalent to institutional Christianity in Europe made

is Regarding the Iwakura group's contribution to kokutai discourse, the reader may consult Okubo Toshiaki, "Meiji kenpō no seitei katei to kokutairon - Iwakura Tomomi no Taisei kiyō ni yoru sokumenkan", in Rikken seiji: Ronshü nihon rekishi 11 (Tokyo, 1975; 1st ed. 1954). Regarding the development of the notion of kokutai, see also Emura, Jiyū minken, pp. 221-224, and Maruyama Masao, Nihon no shiso (Tokyo, 1961), pp. 33-35. 
it desirable to base Japan's symbolic foundation on the authority of the emperor. Extension of the emperor's prerogatives was necessary in this regard in order to forge a sense of national solidarity and civic morality. At the same time, Itō argued against an overly absolutist view by stating that the aim of the modern constitution is "to limit the power of the sovereign and to protect the rights of subjects". Itō insisted that a constitutional government should protect the life and property of the people by means of a legal system; otherwise, it was meaningless to institute a constitution. ${ }^{46}$ Itō's view on citizenship bore at least a family resemblance to what some populist activists had envisioned. Many activists accepted the reasoning about the continuity of kokutai, while they attempted to expand the civic rights and political participation of the people (understood in terms of seitai) as widely as possible. ${ }^{47}$

On the surface, the Meiji Constitution of 1889 had a clear absolutist character in so far as it defined the emperor as the fountain-head of sovereign power. The emperor was described as a sacred personage who voluntarily promised to rule the country on a constitutional basis. $\mathrm{He}$ held the right to reign over Japan by virtue of his unbroken line of descent from the divine ancestors. He was also commander-in-chief of the Japanese army and navy. Though the emperor's prerogatives looked impressive on paper, in practice his power was exercised only through delegation to others. He therefore had no responsibility for the outcome of political decisions. The emperor's lack of direct involvement in affairs of state meant that the continuity of kokutai could be readily maintained.

Given the assumption of an imperial authority uncontaminated by the pragmatic realities of politics, the stability of kokutai could be protected while the government could adapt to the needs of procedural democracy. The Japanese people were defined in the constitution as shinmin (subjects) of the emperor, subjects who enjoyed a number of civic rights and responsibilities. As long as the emperor did not directly exercise his prerogatives, which included certain emergency powers in the event of a national crisis, the constitutional framework guaranteed that democratic procedures would prevail in day-to-day practice. Indeed, the Meiji constitution was designed to accommodate the changing political needs of the time. With it, Japan developed parliamentary politics based upon a party system, and even introduced universal male suffrage in 1925. By the early twentieth century, when the acceleration of industrialization increased the size of the urban bourgeoisie and working class, the Diet came to play a central role in the political process, contrary to the original expectation of the oligarchic constitution-writers. ${ }^{48}$ At the same time, provision for

${ }^{46}$ Hirano, "Kenpō no seitei", in Fukushima, Nihin kindaihō taisei, pp. 301-302.

${ }^{47}$ Ikai Takaaki, "Jiyū minken undō to sensei seifu", in Kōza, Nihon rekishi 7 kindai I, pp. 286-295.

${ }_{48}$ Gordon, Labor and Imperial Democracy, p. 2. The reader may also wish to consult R.H.P. Mason, Japan's First General Election 1890 (Cambridge, 1969). 
the emperor's intervention in political emergencies and the lack of civilian control of the military in the Meiji constitution paved the way for the emergence of pre-war authoritarian militarism legitimated by the claim of national emergency. The ambiguous definitions of and distinction between kokutai and seitai were utilized in order to suppress political liberties in the subsequent development of authoritarian policies in the 1930s.

Following the promulgation of the Meiji Constitution in 1889, consciousness-raising campaigns were conducted on an unprecedented scale, with the intention of raising the level of civic morality and loyalty. The concept of kokutai, that is, the nation's symbolic identity embodied in an unbroken imperial tradition, provided the content of these programs. Although these various ideological campaigns were coordinated by agents of the government who had various intentions, they were also promoted by a variety of private agents and interests. The aggregated result was what Carol Gluck has called the "birth of Japan's modern myth".

In sum, the development of a limited but expanding democracy in Meiji Japan resulted from a process of negotiation and concessions by the state to popular social forces. In this process of social negotiation, the emperor became the symbolic lever for change in the hands of both state officials and the pro-democratic opposition forces. The scale and aggressiveness of the Freedom and People's Rights Movements provided a critical impetus to the direction of the Japanese style of modern political citizenship. At the same time, it was this political process, a set of interactions between opposition movements and the Meiji oligarchy, that crystallized the distinctive identity of Japanese pre-war nationhood - the so-called kokutai - and expanded the authority of the emperor. In this process of symbolic discourse, the emperor emerged as a paternal image, a potent political symbol as well as a social rescuer when crisis intervention was required. Having little direct control of daily government affairs, and being isolated as a sacred figure, the emperor could become a symbolic agent for change in any political camp in so far as the constitutional system prevented his being soiled by the dirty realities of polities.

When the Japanese quasi-fascist movements gained in power in the late 1920 s, the activists frequently expressed a distinctly romanticized view of the emperor as a savior who would reform society when his "true will" - as was thought - was reflected by the government. A wave of political assassinations of parliament members and business leaders by these new radicals swept over Japan. Subsequently, with the slogan of "Shōwa restoration", Japan entered an era of barbarous militarism in the 1930s in the emperor's name. Paradoxical as it may seem, the outwardly progressive introduction of modern citizenship rights, together with the construction of the authoritarian imperial system in Japan, were 
in this sense ill-fated twin offspring of the process of Meiji nation-building.

\section{SOME COMPARATIVE OBSERVATIONS}

In this paper, I have examined the close and intricate connections between the process of Meiji nation-building and the development of public discussion of citizenship rights. To be sure, modern citizenship rights in the West - conceived as "equalizing principles" for the inhabitants of nation-states - have always been connected to the evolution of nation-states and nationalism. From this perspective, a tight relationship between nation-building, nationalism and citizenship rights in Meiji Japan itself is not exceptional by itself. In Europe, however, the development of modern national citizenship presupposed a long preparatory period. Rogers Brubaker has remarked with respect to France:

Territorial state-membership and municipal citizenship are, in some respects, polar opposites. The theory and practice of citizenship as a general, abstract status, characterized by equality of citizens before the law, was a product of the centralizing, rationalizing policies of absolutist territorial rulers. The theory and practice of citizenship as a privileged status, defined by participation in the business of rule, was a product of the defensive exclusiveness with which the politically privileged administered the affairs of the more or less autonomous classical, medieval, and early modern city. Yet the two traditions were joined in the French Revolution. ${ }^{49}$

In contrast, in the case of England, the state was built on "a conjunction

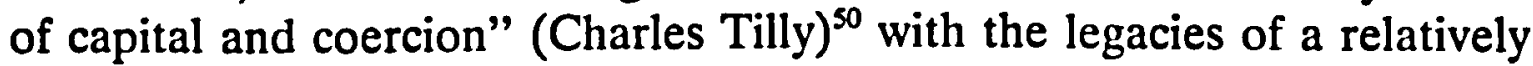
low degree of medieval municipal autonomy and a strong tradition of constitutionalism as well as an elitist parliament that curbed the power of the monarch. In England, the construction of citizenship rights did not take the French path of synthesis of antagonistic social forces. Instead, as Margaret $\mathrm{R}$. Somers recently observed, the creative employment of the nation-wide legal institutions played an important role in the formulation of modern citizenship rights. ${ }^{\text {II }}$ In this light, Meiji Japan's construction of political citizenship rights does not bear a close resemblance to either the French or the English model.

The question remains whether the experience of Meiji Japan can be properly compared to the German pattern of development of political rights as I stated at the beginning of this paper. I offer a twofold answer.

49 Rogers Brubaker, Citizenship and Nationhood in France and Germany (Cambridge, MA, 1992), p. 43.

so Charles Tilly, Coercion, Capital, and European States AD 990-1990 (Oxford, 1990), p. 159.

s1 Margaret R. Somers, "Citizenship and the Place of the Public Sphere: Law, Community, and Political Culture in the Transition to Democracy", American Sociological Review, 58 (1993), pp. 587-620. 
If we were to select one case from among the European examples, the German experience is the one most comparable to the case of Meiji Japan. The similarities cannot be ascribed solely to Japan's intentional adoption of the Prussian constitutional model. Both countries shared similar patterns of long-term social developments, in terms of the construction of a modern state in a society with lingering feudal traditions, the historically dominant role played by a warrior class, late development with respect to capitalism and industrialization, and a major role for the state in modern institution-building. In both cases, we also observe the relative weakness of organized power of the urban bourgeoisie during the critical period of development of citizenship rights. Germany had no experiential counterpart to the French Revolution, as a source of inspiration for a concept of national citizenship. In Prussia, unlike France, "the foundations of citizenship were established by the absolute monarch and through the Stände"..$^{52}$ This configuration resembled the situation of Meiji Japan, in that the foundations of modern citizenship were established under an outwardly "absolutist" monarch in a society still burdened with the legacies of feudalism. From a Eurocentric viewpoint, if one seeks elsewhere for a "comparable" case on the basis of long-standing patterns of social development, it is probably Japan that offers a useful comparison with the European experiences. Japan obviously underwent a lengthy period of feudalism, during which it was ruled by military landholders. In addition, its internal pacification during the early modern period has parallels to some European patterns. Japan's nineteenth-century race to construct a modern nation-state, and its subsequent "successful" economic overtaking of other industrial nations make Japan a good instance for comparison with Germany, itself a successful but atypical case of industrialization within Europe.

Upon closer examination, however, one uncovers some important aspects of the Meiji experience which might be overlooked if one peers only through the German lens. Although the notion of German "exceptionalism" - a view that has been criticized by recent revisionist historians $^{53}$ - may hold some truth within the specific framework of intra-European comparison, Germany still shared the common European patrimony of social and cultural resources. Two major points stand out. First, in the German case, as with other European societies, the medieval and early modern cities developed a measure of political autonomy, and citizenship in these cities conveyed certain political privileges. Although medieval municipal citizenship differed in many respects from modern

52 Brubaker, Citizenship and Nationhood, p. 61. See also Gerhard Oestreich, "The Estates of Germany and the Formation of the State", Neostoicism and the Early Modern State (Cambridge, 1982); Hans Kohn, Prelude to Nation-States (Toronto, 1967); Gianfranco Poggi, The Development of the Modern State: A Sociological Introduction (Stanford, 1978). ${ }^{33}$ See, for example, D. Blackbourne and G. Eley, The Peculiarities of German History (Oxford, 1984). 
citizenship rights, the tradition of municipal citizenship was an indispensable ingredient, socially and ideologically, for the expansion of civic and political rights in nineteenth-century Germany. This precondition of municipal autonomy in the pre-modern cities in Europe and its effects on the legal status of persons were, as Max Weber pointed out, "a striking contrast to the Asian conditions". ${ }^{54}$ Germanic cities, such as the Hansa towns, were no exception to this general description. From that perspective, the power of the states expanded by transforming municipal and corporate citizenship rights into state-wide membership, and removing internal political boundaries.

Since Japan did not have a strong history of politically autonomous municipalities, it did not develop an indigenous socio-cultural resource connected to the rights of independent towns. Not only that, the formation of the Tokugawa state forcibly deprived medieval corporate entities (i.e. samurai estates, corporate villages, guilds and Buddhist temples) of their previous socio-political autonomy. Hideyoshi's disarmament of the commoners broke down the incorporated structures of the sō-son villages. The separation of the samurai from land tenure destroyed the autonomy of the medieval samurai estates. All these measures suppressed the construction of social mechanisms potentially capable of countering the ruler's power. With little institutional preparation for modern citizenship rights, Meiji Japan was thrown directly into the turbulent processes of contemporary nation-state building and the development of participatory politics. Consequently, the regime incorporated all available indigenous cultural resources, ranging from popular feelings of yonaoshi and elitist samurai commitments to public responsibility and symbolic devotion to the emperor in order to formulate a political consensus for citizenship within a remarkably short period. At the same time political elites attempted to assimilate Western political philosophies and concepts in order to facilitate rapid entry into a new era of modern national identity and constitutional definitions of citizenship.

The second point concerns the different social location and tradition of law in Japan. Under the Tokugawa, law was essentially the written expression of the ruler's will. Legal compilations consisted of little more than collections of the shogun's orders. There was no representative assembly of any sort, and no correlative contractual legal framework. In addition, there was nothing corresponding to Western notions of divine or natural law to which rulers themselves were subject. Traditional law in Japan could not serve as a source of inspiration for concepts of human liberty and popular political rights. Although it is often remarked that Germany also came late to modern constitutionalism, the Germanic societies did share the common European tradition of natural and positive law. The tradition of contractual rule, the concept of a contract

st Max Weber, Economy and Society (Berkeley, 1978; 1st ed. 1968), p. 1236. 
made with the sovereign, evident in precedents such as the Magna Carta (1215), the Golden Bull of Hungary (1222) and the Aragonese Privileges (1283), was not an alien concept in Germanic societies. The early modern German territorial states were also set within the framework of the Holy Roman Empire, in which the office of Emperor, "King in Germany", was elective. In his capacity as an elected monarch, the Emperor was never independent of those who had elected him. ${ }^{55}$ Most recently, Brian Downing has argued that many of the characteristics of late medieval European states, such as the existence of decentralized polities with considerable local autonomy, representative assemblies, constitutionalism, and an elitist valuation of freedom and independence distinguished Western Europe from other parts of the world and predisposed it toward the development of liberal democracy. ${ }^{56}$ By contrast, Japan came of age in the late nineteenth century without any traditions of contractual rule or a representative assembly to check the arbitrary power of the sovereign.

Given these two points of contrast, the lack of independent municipalities and a tradition of natural law in Japan, there was a significant difference between Japanese and German late developments in terms of the preconditions of the development of modern citizenship rights. In this sense, one can also describe Meiji Japan's experience with respect to codifying citizenship rights as much more temporally compressed than that of Germany.

This revised understanding brings us to reevaluate the timing of Japan's reentry into world politics. Meiji Japan confronted pressures from the West only in the late nineteenth century, unlike China's earlier encounter with Western imperialist forces. Japan no doubt was fortunate that the primary interests of the Western powers concerned trade and economic benefits rather than territorial annexation. Furthermore, when Japan entered the arena of international politics in the mid-and late nineteenth century, the process of European industrialization was leveling off. Consequently, the focus of Western interests in Japan was redirected toward the development of profitable and stable trade relations. From the Western viewpoint, Japan was a small but potentially lucrative market for manufactured goods as well as a desirable source of raw materials. As a result, the Western capitalist countries acted in the interests of their bourgeois classes and pressured the Japanese government to create a Western-style legal environment for the protection of their economic transactions.

ss Gerhard Oestreich, "From contractual monarchy to constitutionalism", in Neostoicism, pp. 166-186; Harold J. Berman, Law and Revolution: The Formation of the Western Legal Tradition (Cambridge, MA, 1983).

so Brian M. Downing, The Military Revolution and Political Change: Origins of Democracy and Autocracy in Early Modern Europe (Princeton, 1992). 
Many scholars assume that the legal requirements of an emerging capitalist society are responsible for the rise of modern citizenship rights. In the Japanese case, the demand for legal revisions conducive to capitalist transactions was presented not primarily from "below", from the maturation of an indigenous capitalist economy, but rather as a by-product of international pressures. In contrast, on the domestic front, popular movements organized by former samurai and well-to-do farmers pushed the oligarchy in the direction of modern constitutional politics. The necessity of mobilizing a reluctant population for the tasks of building a modern nation-state - especially the construction of a national standing army based upon conscription, and the introduction of national taxation - also strengthened internal arguments for instituting a system of popular political participation.

The preceding argument brings me to my concluding observation. Though comparisons between Japan and the late-developing European countries may articulate some important features of the Japanese experience, they may also overlook another distinctive aspect. Japan was the first non-Western society to industrialize successfully and also to construct a system of constitutional participatory politics. Meiji Japan's experience with codifying civic and political rights anticipated the experiences of many modern Third World countries, as well as countries from the former Communist bloc. These nations have discovered that the construction of modern legal and political systems is conditioned by the interplay of international and domestic pressures. In particular, demands from advanced industrial countries to introduce a democratic political system and a market economy into these countries were closely related to the need for creating favorable environments conducive to stable capitalist transactions. Implanting First World political and economic institutions in a completely alien institutional environment is a risky political business, however. This understanding induced the Meiji leadership to revive the ancient myth of the emperor, which later turned out to have a detrimental effect not only for Japanese democracy but for neighboring countries as well, when he became the symbol of Japanese imperialism. We may hope, then, that present-day Russia, a state which finds itself in a similar predicament to the one that Meiji Japan struggled to overcome, will find a better solution for the problem of internal solidarity than the invention of a new emperor. 